\title{
Identification of Allelochemicals from Terminalia Chebula
}

\author{
Manikandan, M. \& Rejula M.
}

\begin{abstract}
This study was an experiental research to identify the chemicals contained in terminalia chebula.The dried leaves and barks were ground to a fine powder in a Wiley Mill (40 mesh), using this powder for aqueous extract prepared by the method of Heisey (1990). Bioassay studies were also carried out following the method of Heisey (1990). The extraction of phenolic compounds for GC analysis was carried out by the method of Kil and Yum (1983). The comparison of the leaf and bark extracts was done. The result of our study showed that the leaf extracts of the T.chebula contains more quantity of hydroquinone, trans-cinnamic acid, gentisic acid, vanillic acid, syringic acid and transferulic acid (phnolic acids) otherwise known as allochemicals than the bark and were more inhibitory to seeding growth of Cassia occidentals and Crotalaria retusa than the bark extracts in bioassay studies. The implication is that Terminalia Chebula will be extremely useful in future to control the weed growth in agroecosystem.
\end{abstract}

KEY WORDS: Terminnlia chebula, Cassia occidentals, Crotalaria retusa and allelo chemicals.

\section{Introduction}

Plants produce a large variety of secondary products containing hydroxylated aromatics rings these substance are classified as allelochemicals, most of which are synthesized from phenylalanine, a product of the shikimic acid path way (Taiz and Zeiger 1991). Phenolic acids in aerial parts, roots of allopathic crops actively exude phenolics such as caffeic, chlorogenic, isochlorogenic, p-coumaric, phydroxy benzoic and ferulic acids were detected in alfalfa root 
exudates and vegetative residues (Abdul Rahman and Habib 1989). These secondary metabolic products may be released in to environment, generally the rhizosphere in sufficient quantities to affect neighboring plants. Mostly research on allelopathy has been focused on the effect on interactions among weed species (Willison and Rice, 1968, Rasmussen and Rice 1971). The objectives of this study were to:

(i) Develop a method of weed control by using allelopathic plant

(ii) Quantify the allelopathic potential of Terminalia Chebula on weeds

(iii) Identify the plant parts that are the most important source of allelopathic substances

(iv) Identification of phenolic acids (Allelochemicals)

\section{Methodology}

Mature fresh leaves and barks of the Terminalia chebula were collected from Srivilliputur Reserve Forest, Tamil Nadu, India. Leaves and barks were dried in an oven at $60^{\circ} \mathrm{c} \pm 2^{\circ} \mathrm{c}$ for four days powdered (40 mesh) and used for phenolic acid extraction and bioassay studies. Seeds of the Cassica occidentalis and Crotalaria retusa (weeds) were collected from Tamil Nadu Agricultural University, Coimbatore, Tamil Nadu, India. The dried leaves and barks were ground to a fine powder in a Wiley Mill (40 mesh), using this powder for aqueous extract prepared by the method of Heisey (1990).

\section{Preparation of Aqueous Extract}

Ten grams of leaf and bark powder dissolved separately in $100 \mathrm{ml}$ of distilled water in a beaker and kept for $24 \mathrm{hr}$ at room temperature $\left(28^{\circ} \mathrm{c} \pm 2^{0} \mathrm{c}\right)$ with occasional swirling. The solution was filtered through what man N0 1 filter paper and the volume was made up to $100 \mathrm{ml}$ with distilled water. The aqueous extract was diluted with 
water to get $5,10,15$ and $20 \%$ concentrations. The dilutions corresponded to $0.5,0.1,0.15$ and $0.2 \%$ of water extractable materials.

\section{Bioassay Studies}

Bioassay studies were carried out following the method of Heisey (1990). Ten weed seeds were placed on what man N0 1 filter paper in petriplates $(9 \mathrm{~cm} \times 2 \mathrm{~cm})$. Petriplates were moistened with $2 \mathrm{~m} 1 /$ plate of leaf /bark aqueous extract/distilled water (control), and incubated in dark $28^{\circ} \mathrm{c} \pm 2^{0} \mathrm{c}$. The experimental design was a randomized complete block with five replicated for each treatment and control. Germination percentage, plumule and radicle lengthy were measured after three days.

\section{Extraction of Phenolic Acid for GC Analysis}

The extraction of phenolic compounds for GC analysis was carried out by the method of Kil and Yum (1983). 2 grams of powdered leaf and bark samples were defatted using hexane. Then the defatted powder was mixed with $100 \mathrm{ml}$ of $70 \%$ methanol: $70 \%$ acetic acid $(20 \%)$ and centrifuged at 3,000 rpm for 5 minutes. The resulting supernatant was saved and concentrated to $20 \mathrm{ml}$. The $\mathrm{P}^{\mathrm{H}}$ of the supernatant was adjusted to 2.0 with $6 \mathrm{~N} \mathrm{HCL}$. Then this solution was centrifuged at 3,000 $\mathrm{rpm}$ for $5 \mathrm{~min}$ the residues were discarded and the supernatant was mixed and partitioned with $20 \mathrm{ml}$ of hexane: distilled water (1:1) 5 times. The aqueous solution was saved and it was extracted with equal volume of ethanol: ethyl acetate $(1: 1)$ for 5 times. The resulting ethanol: ethyl acetate solution was concentrated and used for the analysis of phenolic acid by GC.

Phenolic acids were identified GC (Hewlettpackard-5890USA) using $\mathrm{J} \& \mathrm{~W}$ fused silica capillary and SE-54coloum $(30 \mathrm{mx} 0.2 \mathrm{~mm})$ column temperature was at $90^{\circ} \mathrm{C}(5 \mathrm{~min}) 4^{\circ} \mathrm{C} / \mathrm{min} 250{ }^{\circ} \mathrm{C}(20 \mathrm{~min})$. Injector and deducted temperature was $280^{\circ} \mathrm{C}$. The head pressure of column was 30Psi and split ration was 36:1 the detector was FID the volume of the sample injected was $0.5-1.0 \mu 1$. Comparing the retention times of the 
peaks with those of commercial Sigma and Aldrich phenolic acid samples were used for the identification of each peak.

\section{Results and Discussion}

In bioassay studies of $T$. chebula on $C$ occidentails the germination of plumule and radical length was decreased in all concentrations. In the highest concentration this inhibition was maximum (Table 1 and 2). The inhibitory effect on the seed germination by leaf aqueous extracts was gradual while the bark extract of $T$.chebula drastically inhibited the seed germination. A maximum of $28 \%$ reduction in germination was observed at $20 \%$ leaf extract

The reduction in plumule length by aqueous leaf extracts was gradual but the bark extracts showed rapid decreases in plumule length. The maximum of $22 \%$ and $60 \%$ reduction in plumule length was recorded at $20 \%$ leaf and bark extracts respectively.

A similar pattern of decrease was observed in radicle length of C.occidentalis seeds treated with leaf and bark aqueous extracts maximum of $22 \%$ and $42 \%$ reduction in radical length was noticed at $20 \%$ concentration of leaf and bark respectively

The aqueous leaf and bark extracts of T.chebula were inhibitory to the seed germination, plumule and radical length of C.retusa seeds. The maximum inhibitory effect was observed at the highest concentration (Table 3 and 4). The reduction in seed germination was gradual by the treatment of leaf aqueous extract of T.chebula, where as the reduction was rapid by the bark aqueous extracts treatment. The maximum reduction of $28 \%$ was recorded at $20 \%$ leaf and bark aqueous extract concentration respectively.

The inhibition of plumule length by the aqueous bark extract was more than the leaf aqueous extracts. At the highest concentration both the leaf and bark aqueous extracts of T. chebula showed 22\% and 60\% reduction in plumule length respectively. The reduction in radicle 
length was $22 \%$ at $20 \%$ leaf aqueous extract, while at the same concentration there was only $42 \%$ reduction observed in radicle length in bark aqueous extract.

\section{Identification of phenolic acid}

The GC analysis of phenolic acids in bark and leaf of Terminalia chebula showed the presence of following phenolic acids:

- Phenolic acid in T.chebula leaf: Hydroquinone (27.7ug/grams), trans-cinnamic acid (20.3ug/grams), genetisic acid (153.8 ug/g), vanillic acid (34.4 u/grams), syringic acid (11.7ug/grams) and trans-ferulic acid (67.2ug/gram)

- Phenolic acid in T.chebula bark: Hydroquinone (15.8ug/g), salicylic acid (40.3 ug/g), gentistic acid (3.2ug/g), vanillc acid $(4.2 \mathrm{ug} / \mathrm{g})$, proto catechuic acid $(5.7 \mathrm{ug} / \mathrm{g})$, syringic acid $(49.2 \mathrm{ug} / \mathrm{g}), \mathrm{p}$-coumaric acid $(30.1 \mathrm{ug} / \mathrm{g})$ trans ferulic acid (4.2 $\mathrm{ug} / \mathrm{g})$ and caffeic acid (2.1 ug/g).

The result of our study showed that the leaf extracts of the T.chebula were more inhibitory to seed germination in the plants tested than the bark extracts in bioassay studies. Heisey (1990) has reported similar results. He observed that the leaflets among the various plant parts of Ailanthus altissima showed the highest inhibitory effect on seed germination several weed and crop species. Leaf extracts of several trees like Grewia oppositifolia, Ficus roxburghi and Bauhinia variegate tested by kaletha et.al (1996) showed a higher rate of inhibition on the germination of maize, cowpea, finger millet and soybean. Since the quantities of allelochemicals very among different plant tissues (Putnam and Duke, 1978 and rice, 1984) the higher rate of inhibition by leaf extracts may be explained by the higher amount of allelochemicals present in them. In fact the content of Phenolic compounds was higher in leaf extracts than the bark extracts as is evident from T.chebula Phenolic acid studies. 


\section{Conclusion}

P-coumaric acid has been reported (Lee and Monsi, 1963) as the important allelochemicals from red pine and it has been implicated in respiration and $\mathrm{Ca}^{++}$ion uptake and consequently in inhibition of mung bean hypocotyls length (Demos etal.1975) syringic acid showed a significant reduction in mung bean hypocotyls length with out inhibiting the respiration and $\mathrm{Ca}^{++}$uptake and it inhibited the root elongation in wheat, rye and mung bean (Vaughan and Ord, 1991) above this evidence the inhibition pf radical, plumule and seed germination may due to the presence of these phenolic acids. These allochemicals also found in the leaf of T.chebula is inhibitory to seeding growth of Cassia occidentals and Crotalaria retusa than the bark extracts in bioassay studies. The implication is that Terminalia Chebula will be extremely useful in future to control the weed growth in agroecosystem.

\section{References:}

Abdul Rahman, A.A. and Habib, S.A. (1989). Allelopathic effect of alfalfa (Medicogo sativa) on blady grass (Imperat cylindrica) Journal of Chemical Ecology.15: 2289-2300.

Al-saadawi, I.S. and Rice, E.L. (1982). Allelopathic effect of polygonum aviculare L. II. Isolation, characterization and biological activities of phytotoxins. Journal of Chemical Ecology.8: 1011-23

Demos, E.L., Woolwin, M, Wilson, R.H. and Mcmillan, C. (1975). The effect of ten phenolic compounds on hypocotyls growth and mitochondria metabolism of mung bean. American Journal of Botany.62: 97-102.

Heisey, R.M. (1990). Allelopathic and herbicidal effects of extracts from tree of heaven (Alianthus altissima) American Journal of Botany..77: 662-670.

Kaletha, M.S., Bhatt, B.P and Todatria, N.P. (1996). Tree-crop interaction in traditions in traditional agro forestry systems of 
Grahewal Himalaya.I. Phytotoxic effects of farm trees on food crops. Allelopathy Journal 3:247-250.

Kil, B.S.and Y.J., Yim. (1983): Allelopathic effects of Pinus densiflora on under growth of red pine forest. Journal of Chemical Ecology.9:1135-1151.

Lee, I.K. and Monsi, M. (1963). Ecological studies on Pinus dendsiflora forest .I. effect of plant substances on the floristic composition of the under growth. BotanyMagazine.76: 400413.

Putnam, A.R. and Duke, W.B. (1978). Allelopathy in agro ecosystems. Annual.Review of Phyto pathology. 16:431-451.

Rasmussen, J.A and Rice, E.L. (1971). Allelopathic effect of Sporobolus pyramidatus on vegetation patterning. American Midland Naturalist, 86:309-326.

Tang, C.S and young, C.C. (1982). Collection and identification of allelopathic compounds from the undisturbed root system of Bigalta limporgtass (Hemarthria altissima). Olant physology.69: 155-161.

Vaughan. and Ord, B.G.(1991). Extraction of potential allelochemicals and their effects on root morphology and nutrient content. In.plant root growth an ecological perspective (Ed), D.Atkinson, Black Well Scientific Publications London, Po.399-421.

Wilson, R.E and Rice, E.L. (1968). Allelopathy as expressed by Helianthus annus and its role in old-field succession. Bulletin Torrey Botanical Club 95:432-448 
Table 1: Bioassay studies of aqueous leaf extract of Terminalia chebula on seed germination and seedling growth of Cassia occidentalis

\begin{tabular}{|l|l|l|l|}
\hline & \multicolumn{3}{|c|}{ Leaf Extract } \\
\hline $\begin{array}{l}\text { Concentration } \\
\%\end{array}$ & Germination \% & $\begin{array}{l}\text { Plumule length } \\
(\mathrm{cm})\end{array}$ & $\begin{array}{l}\text { Radicle } \\
\text { length } \\
(\mathrm{cm})\end{array}$ \\
\hline Control & $70 \pm 7.0$ & $4.5 \pm 0.4$ & $3.5 \pm 0.3$ \\
5 & $65 \pm 6.2$ & $4.2 \pm 0.4$ & $3.5 \pm 0.3$ \\
10 & $60 \pm 6.0$ & $4.0 \pm 0.3$ & $3.2 \pm 0.3$ \\
15 & $54 \pm 5.0$ & $3.8 \pm 0.4$ & $3.0 \pm 0.2$ \\
20 & $50 \pm 5.0$ & $3.5 \pm 0.3$ & $2.7 \pm 0.2$ \\
\hline
\end{tabular}

Table 2: Bioassay studies of aqueous bark extract of Terminalia chebula on seed germination and seedling growth of Cassia occidentalis

\begin{tabular}{|l|l|l|l|}
\hline & \multicolumn{3}{|c|}{ Bark Extract } \\
\hline $\begin{array}{l}\text { Concentration } \\
\%\end{array}$ & Germination \% & Plumule length (cm) & $\begin{array}{l}\text { Radicle } \\
\text { length cm) }\end{array}$ \\
\hline Control & $76 \pm 6.8$ & $4.5 \pm 0.4$ & $3.5 \pm 0.3$ \\
5 & $50 \pm 5.0$ & $3.0 \pm 03$ & $3.0 \pm 0.2$ \\
10 & $45 \pm 4.3$ & $2.5 \pm 0.3$ & $2.7 \pm 0.2$ \\
15 & $40 \pm 3.8$ & $2.0 \pm 0.2$ & $2.5 \pm 0.2$ \\
20 & $36 \pm 3.5$ & $1.8 \pm 0.2$ & $2.0 \pm 0.2$ \\
\hline
\end{tabular}

Table 3: Bioassay studies of aqueous leaf extract of Terminalia chebula on seed germination and seedling growth of Crotalaria retusa

\begin{tabular}{|l|l|l|l|}
\hline & \multicolumn{3}{|c|}{ Leaf Extract } \\
\hline $\begin{array}{l}\text { Concentration } \\
\%\end{array}$ & Germination \% & $\begin{array}{l}\text { Plumule } \\
(\mathrm{cm})\end{array}$ & $\begin{array}{l}\text { Radicle length } \\
(\mathrm{cm})\end{array}$ \\
\hline Control & $60 \pm 6.0$ & $4.0 \pm 0.4$ & $3.5 \pm 0.3$ \\
5 & $50 \pm 5.0$ & $3.0 \pm 0.3$ & $3.0 \pm 0.3$ \\
10 & $45 \pm 4.2$ & $2.3 \pm 0.2$ & $2.7 \pm 0.3$ \\
15 & $40 \pm 4.0$ & $2.0 \pm 0.2$ & $2.0 \pm 0.2$ \\
20 & $30 \pm 3.0$ & $1.5 \pm 0.1$ & $1.4 \pm 0.1$ \\
\hline
\end{tabular}


Table 4: Bioassay studies of aqueous bark extract of Terminalia chebula on seed germination and seedling growth of Crotalaria retusa

\begin{tabular}{|l|l|l|l|}
\hline & \multicolumn{3}{|c|}{ Bark Extract } \\
\hline $\begin{array}{l}\text { Concentration } \\
\%\end{array}$ & Germination \% & $\begin{array}{l}\text { Plumule } \\
(\mathrm{cm})\end{array}$ & $\begin{array}{l}\text { Radicle } \\
\text { length }(\mathrm{cm})\end{array}$ \\
\hline Control & $60 \pm 6.0$ & $4.0 \pm 0.4$ & $3.5 \pm 0.3$ \\
5 & $60 \pm 5.7$ & $3.5 \pm 0.3$ & $3.2 \pm 0.3$ \\
10 & $55 \pm 5.0$ & $3.2 \pm 0.3$ & $3.0 \pm 0.2$ \\
15 & $50 \pm 5.1$ & $3.0 \pm 0.3$ & $2.8 \pm 0.3$ \\
20 & $46 \pm 4.4$ & $2.5 \pm 0.2$ & $2.5 \pm 0.2$ \\
\hline
\end{tabular}

Table 5: Identification and content of phenolic acids in Terminalia chebula leaf and bark by gas chromatography

\begin{tabular}{|c|c|c|c|c|}
\hline \multirow[t]{2}{*}{ S.No } & \multirow[t]{2}{*}{ Phenolic acid } & \multirow{2}{*}{$\begin{array}{l}\text { Relative } \\
\text { retention time } \\
(\min )\end{array}$} & \multicolumn{2}{|c|}{ Content $(\mu \mathrm{g} / \mathrm{g}$ Dr.wt) } \\
\hline & & & Leaf & Bark \\
\hline 1 & Hydro quinone & 18.32 & 27.7 & 15.8 \\
\hline 2 & Salicylic acid & 22.15 & & 40.3 \\
\hline 3 & trans-cinnamic acid & 22.84 & 20.3 & \\
\hline 4 & Gentisic acid & 26.64 & 153.8 & 3.2 \\
\hline 5 & Vanillic acid & 29.79 & 34.4 & 4.2 \\
\hline 6 & Protocatechuic acid & 31.56 & & 5.7 \\
\hline 7 & Syringic acid & 3.52 & 11.7 & 49.2 \\
\hline 8 & P-coumaricacid & 34.46 & & 30.1 \\
\hline 9 & trans -ferulic acid & 38.35 & 67.2 & 4.2 \\
\hline 10 & Caffeic acid & 39.54 & - & 2.1 \\
\hline
\end{tabular}

